А.Ю. Шегедін

Н.О. Амбарова

\section{А.М. Ященко}

Львівський національний медичний університет імені Данила Галицького

Надійшла: 12.06 .2019

Прийнята: 24.06.2019
DOI: https://doi.org/10.26641/1997-9665.2019.2.63-70

УДК: 616.681-056.716-02:616.441-008.64]-018:547.96-092.9

ІМУНОГІСТОХІМІЧНЕ ДОСЛІДЖЕННЯ ЯЕЧОК ПОТОМСТВА ЩУРІВ, ЩО РОЗВИВАЛОСЯ ЗА УМОВ ЕКСПЕРИМЕНТАЛЬНОГО ГІПОТИРОЗУ МАТЕРИНСЬКОГО ОРГАНІЗМУ

Shegedin A.Yu. (D) $₫$, Ambarova N.A., Yashchenko A.M. ID $\varangle$ Immunohistochemical investigation of testicular morphogenesis in offspring rats, developing under the influence of maternal hypothyroidism.

Danylo Halytsky Lviv National Medical University, Lviv, Ukraine

ABSTRACT. Background. Thyroid disorders are currently among the most widespread endocrine pathologies, influencing morphogenesis and histophysiology of multiple organs. Objective. The aim of present investigation was to study the impact of maternal hypothyroidism on the testicular development of rats progeny using immunohistochemical detection of cell proliferation marker Ki-67 and vascular endothelium growth factor VEGF. Methods. Hypothyroidism was induced by daily food supplementation of experimental group rats with $10 \mathrm{mg} / \mathrm{kg}$ of anti-thyroid drug Merkazolil during two weeks before pregnancy, throughout the whole gestation and lactation periods. Testes of their progeny on postnatal days 1st, 10th, 20th and 40th were removed after euthanasia, fixed in Bouin's fluid, embedded in paraffin and subjected to immunohistochemical investigation. Results. On postnatal day 1st in control group rats Ki-67 labeling was restricted to cytoplasmic granularity of gonocytes - fetal germ cells, located centrally in within the seminiferous cords. Under hypothyroid conditions additionally to gonocytes Ki-67 binding was detected in macrophages and Leydig cells, number of both significantly elevated. On postnatal day 10th control group animals demonstrated moderate labeling of Sertoli cells, spermatogonia and gonocytes being completely non-reactive. In hypothyroidism affected testes was revealed disperse distribution of Ki-67 marker with predominant accumulation on the periphery of seminiferous cords and in Leydig cells. On postnatal day 20th Ki-67 reactivity was detected in spermatogenic cells of seminiferous tubules. In hypothyroidism affected animals cytoplasmic granularity labeling of maturating spermatogenic cells was higher compared to control, though seminiferous tubules were smaller in diameter and lacking luminae. On postnatal day 40th Ki-67 labeled predominantly spermatogonia, immunoreactivity of which enhanced under hypothyroid conditions. Distribution of VEGF label was generally similar to that of Ki-67, indicating a direct correlation of cell proliferation intensity on saturation of tissues with oxygen. Unlike Ki-67, VEGF exposed strong reactivity with acrosomal granules of early spermatids on postnatal day 20th, as well as more intense spermatogenic cells labeling compared to Ki-67. Conclusion. Testicular morphogenesis in offspring rats, developing under maternal hypothyroidism, was accompanied by the increased immunoreactivity of spermatogenic cell cytoplasm on postnatal days 20th and 40th with Ki-67 and VEGF, as well as acrosomal granules labeling with VEGF. This trend was supplemented with the increased count of macrophages and Leydig cells in testicular interstitium, decreased count and size of spermatogenic cells, damage of their syncytial complexes, all these signs encompassing degenerative changes in seminiferous tubules.

Key words: immunohistochemistry, rat testes morphogenesis, maternal hypothyroidism.

\title{
Citation:
}

Shegedin AYu, Ambarova NA, Yashchenko AM. [Immunohistochemical investigation of testicular morphogenesis in offspring rats, developing under the influence of maternal hypothyroidism]. Morphologia. 2019;13(2):6370. Ukrainian.

DOI: https://doi.org/10.26641/1997-9665.2019.2.63-70

iD Shegedin A.Yu. 0000-0002-3761-7800

iD Yashchenko A.M. 0000-0002-8422-5834

$\bowtie$ a.shegedin@gmail.com

$\bowtie$ yashchenko_am@ukr.net

(C) SI «Dnipropetrovsk Medical Academy of the Ministry of Health of Ukraine», «Morphologia»

\section{Вступ}

Захворювання щитоподібної залози належать до найпоширеніших ендокринних патоло- гій, охоплюючи близько $3 \%$ населення світу 3 тенденцією до зростання як у популяції в цілому, так і в Україні зокрема [1]. Гіпотироз - клінічний 
синдром, викликаний стійкою тривалою недостатністю гормонів щитоподібної залози тироксину (Т4) та трийодотироніну (Т3) або зниженням їх біологічного ефекту на тканинному рівні. Синдром гіпотирозу, який $є$ найбільш поширеною ендокринною патологією після цукрового діабету 2 типу часто індукується вагітністю, у зв'язку з чим статистика уражень жінок пересічно 20-кратно перевищує аналогічний показник для чоловіків [2]. Упродовж пренатального онтогенезу та дитячого віку тироїдні гормони стимулюють проліферацію та диференціювання нейронів, посилюють процеси росту, стимулюють активність ендокринних залоз, забезпечуючи диференціаціюї і дозрівання органів плода у відповідності до часу гестації [1-3]. Дисбаланс тироїдних гормонів у вагітних чинить негативний вплив на дитячий організм, обумовлюючи підвищену смертність, респіраторний дистрессиндром, гіпотрофію, вроджені вади розвитку, вроджений гіпотироз, кретинізм тощо $[4,5]$.

Донедавна вважалося що не існує прямого зв'язку між функцією щитоподібної залози та гістофізіологією яєчок, однак новітні дослідження продемонстрували тісну залежність різноманітних структур чоловічих статевих залоз від впливу тироїдних гормонів [6-19]. Так, зокрема, на поверхні ядер проліферуючих клітин Сертолі виявлено експресію рецепторів тироїдних гормонів TR $\alpha 1$, редукція яких співпадала 3 припиненням проліферативної активності клітин Сертолі $[6,10]$. Окрім останніх, означені рецептори були виявлені у складі сперматогенних клітин, починаючи від сперматогоній проміжного типу аж до пахітенних сперматоцитів, а також в окремих популяціях клітин інтерстицію яєчок щура [10].

У публікаціях Gao et al. [11], Romano et al. [12] задокументовано присутність у складі клітин Сертолі і Лейдіга, ембріональних статевих клітин гоноцитів, окрім рецепторів тироїдних гормонів, також транспортерів цих гормонів і ферментів дейодиназ, здатних конвертувати Т4 на більш активний Т3. Показано регуляторний вплив тироїдних гормонів на проліферативну активність і диференціацію клітин Сертолі, формування останніми щілинних контактів та становлення гемато-тестикулярного бар'єру [11]. На тлі експериментального гіпотирозу ідентифіковано зменшення розмірів яєчок, у звивистих сім'яних трубочках виявлено дегенеративні зміни - деструкцію клітин базального шару, дезорганізацію і ущільнення синцитіальних комплексів $[6,13]$. Замісна терапія тироксином забезпечувала відновлення ушкодженої статевої функції [14].

Гіпотироз у неонатальному періоді онтогенезу обумовлює подовження терміну проліферації і сповільнює дозрівання клітин Сертолі, що може призводити до незворотного пошкодження яєчок [15]. За умов неонатального гіпотирозу ідентифіковано зменшення маси яєчок, обумовлене зменшенням діаметру звивистих сім'яних трубочок внаслідок блокування сперматогенезу (пригнічення проліферації і диференціації сперматогенних клітин), у поєднанні з редукцією рівня тестостерону, естрадіолу та андрогензв'язувального білка в плазмі крові [16, 17]. Anbalagan et al. [18] встановили, що гіпотироз материнського організму обумовлює зменшення кількості сперматозоїдів, подовження часу їхнього транзиту через канальці придатка, зниження біодоступності тестостерону i функціональної активності адроген-зв'язувального білка.

У попередніх дослідженнях 3 використанням методів класичної гістології, морфометрії та лектинової гістохімії нами було показано, що гіпотироз материнського організму індукує затримку розвитку сім'яників потомства, що проявлялося сповільненням редукції фетальних клітин Лейдіга, сповільненим дозріванням сперматогенних клітин у поєднанні 3 накопиченням ї дегенеративних та проапоптозних форм [19]. Аналіз доступної літератури виявив відсутність публікацій, які б характеризували вплив дисбалансу тироїдних гормонів материнського організму на проліферативну активність і експонування фактора росту судинного ендотелію структурами яєчок потомства, що може представляти інтерес як для теоретичної, так і клінічної андрології.

\section{Мета}

Дослідити вплив експериментального гіпотирозу материнського організму на експресію імуногістохімічних маркерів проліферативної активності клітин (Кі-67) та фактора росту судинного ендотелію (VEGF) у структурних компонентах яєчок потомства щурів на послідовних етапах постнатального морфогенезу.

\section{Матеріали та методи}

Дослід проводили на 25 самках щурів лінії Вістар масою 180-200 г, які були розділені на дві групи: перша - контрольна (10), друга - 3 індукованим гіпотирозом (15). Експериментальний гіпотироз викликали згодовуванням самкам антитироїдного препарату Мерказоліл («Здоров’я», Харків) з розрахунку 10 мг/кг маси тіла. Мерказоліл додавали у їжу у вигляді порошку щоденно протягом двох тижнів до початку вагітності, упродовж усього гестаційного періоду та лактації. Контроль функції щитоподібної залози здійснювали шляхом вивчення іiі морфології та радіоімунологічного визначення гормонів Т3 та Т4. Через два тижні від початку експерименту шляхом щоденного взяття мазків 3 піхви самок контролювали естральний цикл. Самок в стадії еструсу підсаджували до інтактних самців. Перший день вагітності визначали за наявністю сперматозоїдів у піхвових мазках.

Під час роботи з тваринами керувались «За- 
гальними етичними принципами експериментів на тваринах» (Україна, 2001), узгодженими 3 вимогами «Свропейської конвенції щодо захисту хребетних тварин, яких використовують в експериментальних та інших наукових цілях» (Страсбург, 1986), Законом України № 3447-IV від 21.02.2006 «Про захист тварин від жорстокого поводження», Директивою Ради Європи 2010/63/EU, Гельсінською декларацією про гуманне ставлення до тварин.

Для імуногістохімічного дослідження були використані яєчка потомства на 1-у, 10-у, 20-у та 40-у доби постнатального розвитку - періоду, упродовж якого внаслідок адаптації до умов позаутробного існування морфогенетичні зміни досягають найбільшої вираженості. Так, згідно даних Parker et al. [20] упродовж 18-20 доби у щурів відбувається становлення гематотестикулярного бар'єра, опускання яєчок до калитки, перетворення сім'яних тяжів на сім'яні трубочки; з'являються перші округлі сперматиди (26 доба), а відтак - перші довгасті сперматиди (35 доба); окремі округлі сперматиди експонують біля ядер акросомальні шапочки. Завершується морфогенез яєчок щура на 46-у постнатальну добу з вивільненням у просвіт сімяних трубочок довгастих сперматид 19-ї стадії розвитку.

Яєчка забирали після евтаназії тварин шляхом передозування диетилефірного наркозу, фіксували в суміші Буена і заливали у парафін за загальноприйнятою методикою. Зрізи товщиною 5 мкм наносили на адгезивні предметні скельця SuperFrostPlus. Після депарафінізації та регідратації зрізів проводили температурне демаскування антигенів: зрізи поміщали в цитратний буфер pH 6,0 і підігрівали в автоклаві при температурі $+121^{\circ}$ С 8 хвилин.

Активність ендогенної пероксидази пригнічували шляхом інкубації зрізів у $3 \%$ розчині перекису водню протягом 20 хвилин. Відтак проводили інкубацію зрізів 3 первинними антитілами у вологих камерах при температурі $23-25^{\circ} \mathrm{C}$ на протязі 30 хвилин. В якості первинних використовувалися моноклональні антитіла до Ki-67 та VEGF (TermoScientific, США). Титр антитіл підбирався згідно рекомендацій виробника $з$ використанням у якості розчинника спеціального розчину Antibody Diluent (TermoScientific, США). Для ідентифікації продуктів реакції використовували систему візуалізації Quanto (TermoScientific, США) із застосуванням в якості хромогену 3,3'діамінобензидину тетрагідрохлориду.

Для виокремлення ареактивних структур зрізи додатково обробляли гематоксиліном Майєра. Після дегідратації у спиртах висхідної концентрації та просвітлення в трьох порціях ксилолу препарати заключали в полістирол. Місця зв'язування відповідних антитіл визначали за наявністю коричневого осаду.
Інтенсивність реакції оцінювалась напівкількісно двома незалежними спостерігачами. Огляд та фотографування гістологічних препаратів здійснювали за допомогою мікроскопа «Granum», обладнаним камерою «Echoo-Imager 502000 » 3 використанням програми «ToupView $3.7 »$.

Результати та їх обговорення

Імуномаркер Ki-67. На 1-у постнатальну добу у тварин контрольної групи імуномаркер проліферації Кі-67 виявлений у складі цитоплазматичної зернистості гоноцитів (фетальних гермінативних клітин), котрі були локалізовані всередині сім'яних тяжів - в оточенні сустентоцитів (клітин Сертолі) (рис. 1А). На тлі гіпотирозу, окрім гоноцитів, маркер Кі-67 було ідентифіковано також у складі інтерстиційних гландулоцитів (клітин Лейдіга) та макрофагів (рис. 1Б), кількість яких за умов експерименту істотно збільшувалась, що узгоджується $з$ нашими попередніми спостереженнями [19].

На 10-у постнатальну добу у тварин контрольної групи помірна кількість рецепторів Кі-67 була задокументована у складі клітин Сертолі, що віддзеркалює посилення їхньої проліферативної активності. Гоноцити, які мали серединну локалізацію у складі сім'яних тяжів, та розміщені поблизу базальної мембрани сперматогонії, були ареактивними, хоча в останніх спостерігалися фігури мітозу (рис. 1В). На тлі гіпотирозу виявлено дисперсний розподіл маркера 3 переважним його накопиченням на периферії сім'яних тяжів та у складі клітин інтерстицію. Сім'яні тяжі та клітинні елементи у їхньому складі менших розмірів, зі зміненими тинкторіальними властивостями і з порушеннями пошарового розміщення клітин у порівнянні з контролем (рис. 1Г).

На 20-у постнатальну добу в нормі імунолокалізація маркера концентрувалася всередині сім'яних трубочок - у зоні проліферативної активності сперматогенних клітин (рис. 2А). За умов гіпотирозу мітка дисперсно розподілялася у складі цитоплазматичної зернистості дозріваючих сперматогених клітин, реактивність яких була вищою у порівнянні 3 контрольними показниками; сім'яні трубочки меншого діаметру, 3 відсутністю просвіту; розмір сперматогенних клітин збільшений, кількість - істотно редукована (рис. 2Б). Ці спостереження співпадають 3 результатами Maran et al. [16, 17], і узгоджуються 3 отриманими нами раніше даними щодо пригнічення проліферативної активності та затримки дозрівання сперматогенних клітин на тлі материнського гіпотирозу [19].

На 40-у постнатальну добу мітка Кі-67 виявлена у складі сперматогоній, локалізованих у базальному компартменті сім'яних тркбочок; реактивність інших класів сперматогенних клітин була значно слабшою (рис. 2В). Гіпотироз- 
ний стан індукував посилення імунореактивності сперматогенних клітин у поєднанні зі зменшенням їх чисельності, втратою округлої форми, дезорганізацією синцитіальних комплексів (рис.
2Г), що вкладається у концепцію описаних Jannini et al. [6], Cooke [13] дегенеративних змін сім'яних трубочок, індукованих тироїдним дисбалансом.
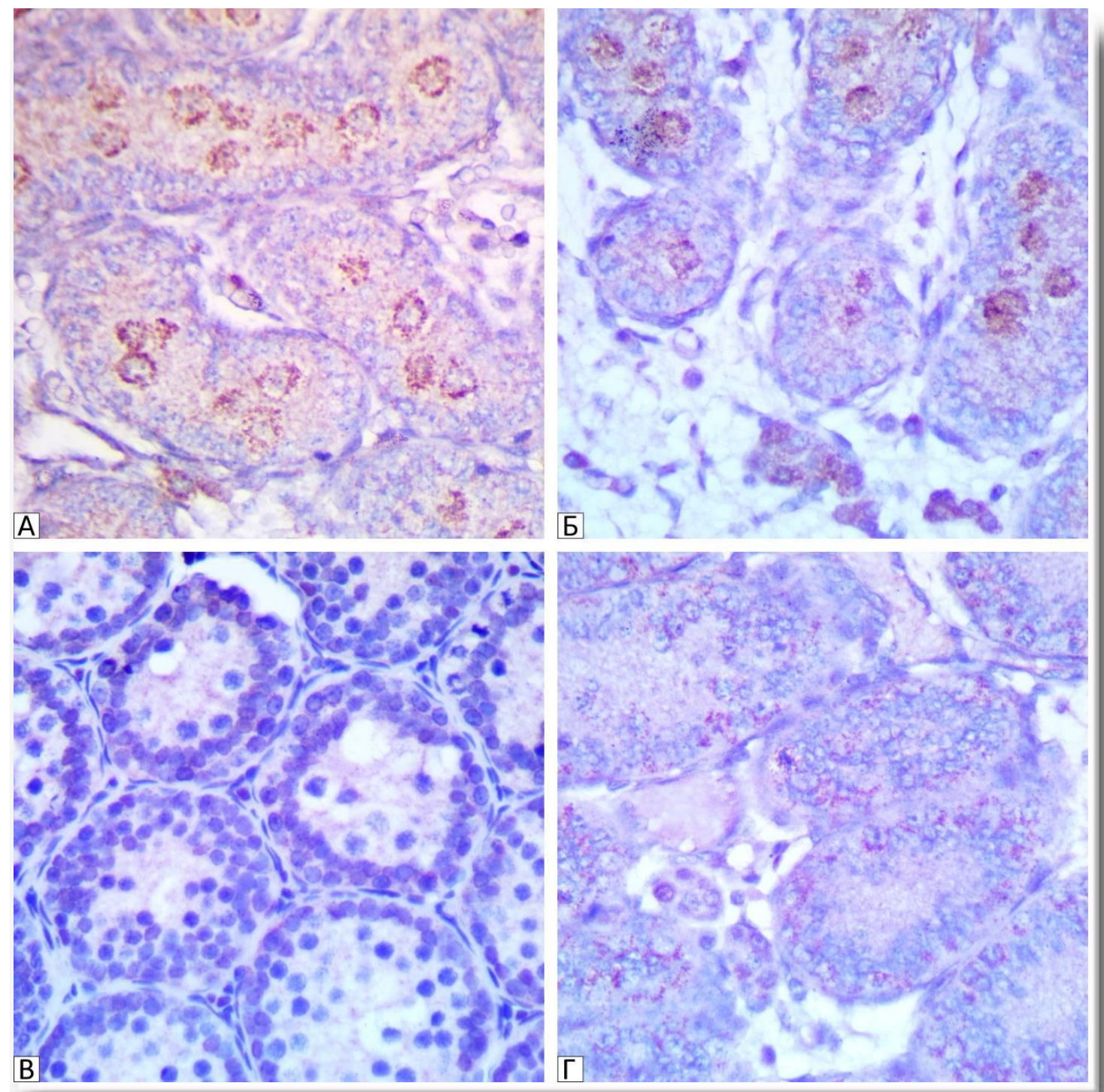

Рис. 1. Гістотопографрія маркера клітинної проліферації Кі-67 у яєчках щурів на 1-у (А, Б) та 10-у (В, Г) доби постнатального онтогенезу. А, В - контроль; Б, Г - яєчка тварин, що розвивалися в умовах експериментального гіпотирозу материнського організму. ×560.

Гістотопографія фактора росту судинного ендотелію VEGF істотно не відрізнялася від такої для Кі-67, що свідчить про пряму корелятивну залежність інтенсивності клітинної проліферації від насиченості тканин киснем. Виявлені відмінності стосувалися реактивності акросомальних гранул ранніх сперматид 3 маркером VEGF, яка була ідентифікована на 20-у та 40-у доби постнатального розвитку у яєчках тварин, що розвивалися за умов гіпотирозу (рис. $3 \mathrm{~A}$ ). На 40-у постнатальну добу з використанням імуномаркера VEGF задокументовано зменшення розмірів сперматогенних клітин, втрату ними округ- лої форми, руйнування синцитіальних комплексів, численні явища апоптозу, що служать віддзеркаленням дегенеративних змін у сім'яних трубочках $[6,13]$.

Виявлена нами невідповідність між підвищеним рівнем експонування маркера проліферації Кi-67 та зменшенням вмісту сперматогенних клітин у поєднанні зі збільшенням їхнього розміру на 20-у та 40-у добу постнатального онтогенезу, правдоподібно, обумовлена переважанням процесів апоптозу у складі сім'яних трубочок, який не скомпенсовувався сигналами щодо посилення проліферації, генерованими Кі-67. 

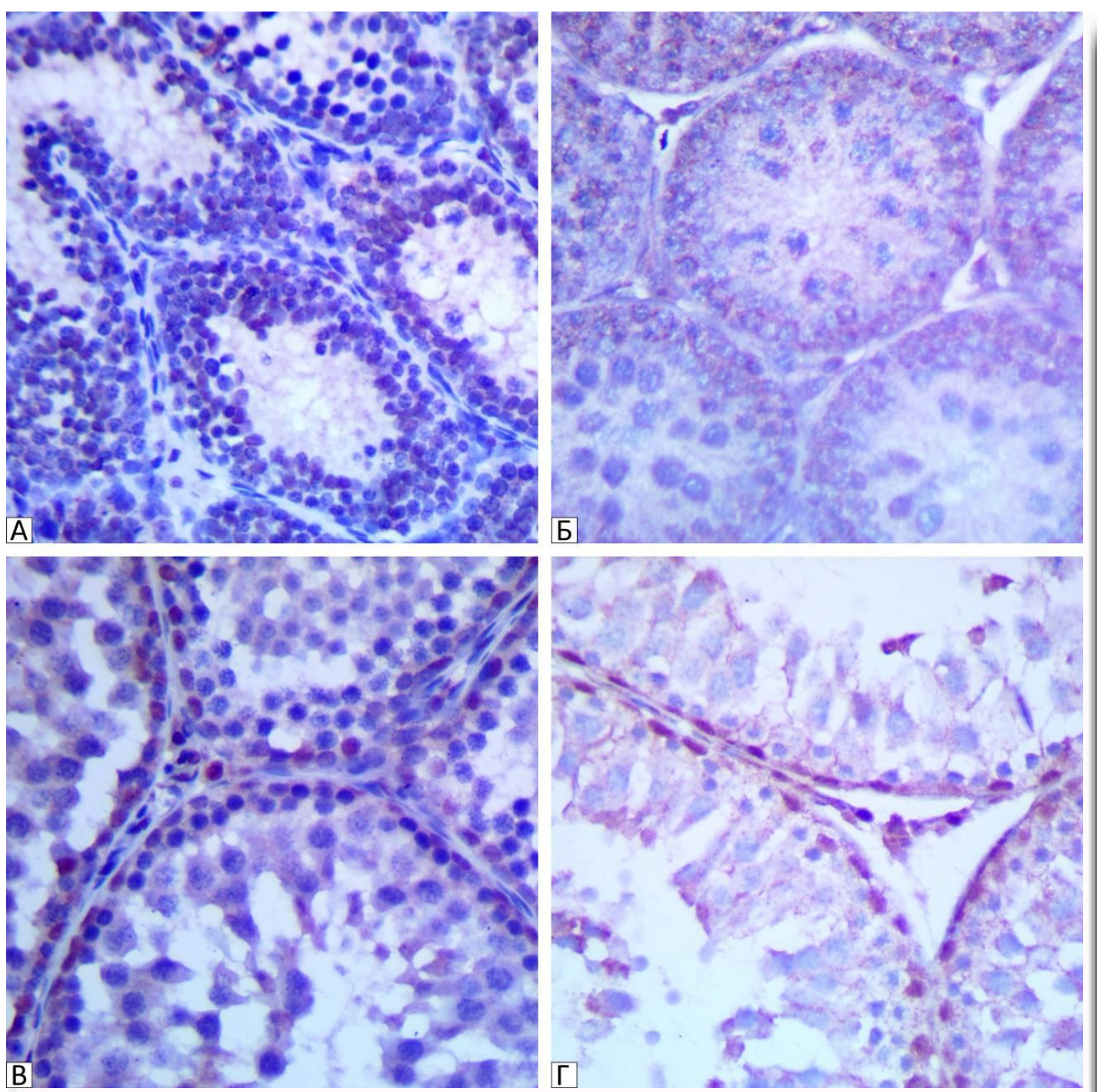

Рис. 2. Гістотопографія маркера клітинної проліферації Кі-67 у яєчках щурів на 20-у (А, Б) та 40-у (В, Г) доби постнатального онтогенезу. А, В - контроль; Б, Г - яєчка тварин, що розвивалися в умовах експериментального гіпотирозу материнського організму. ×560.
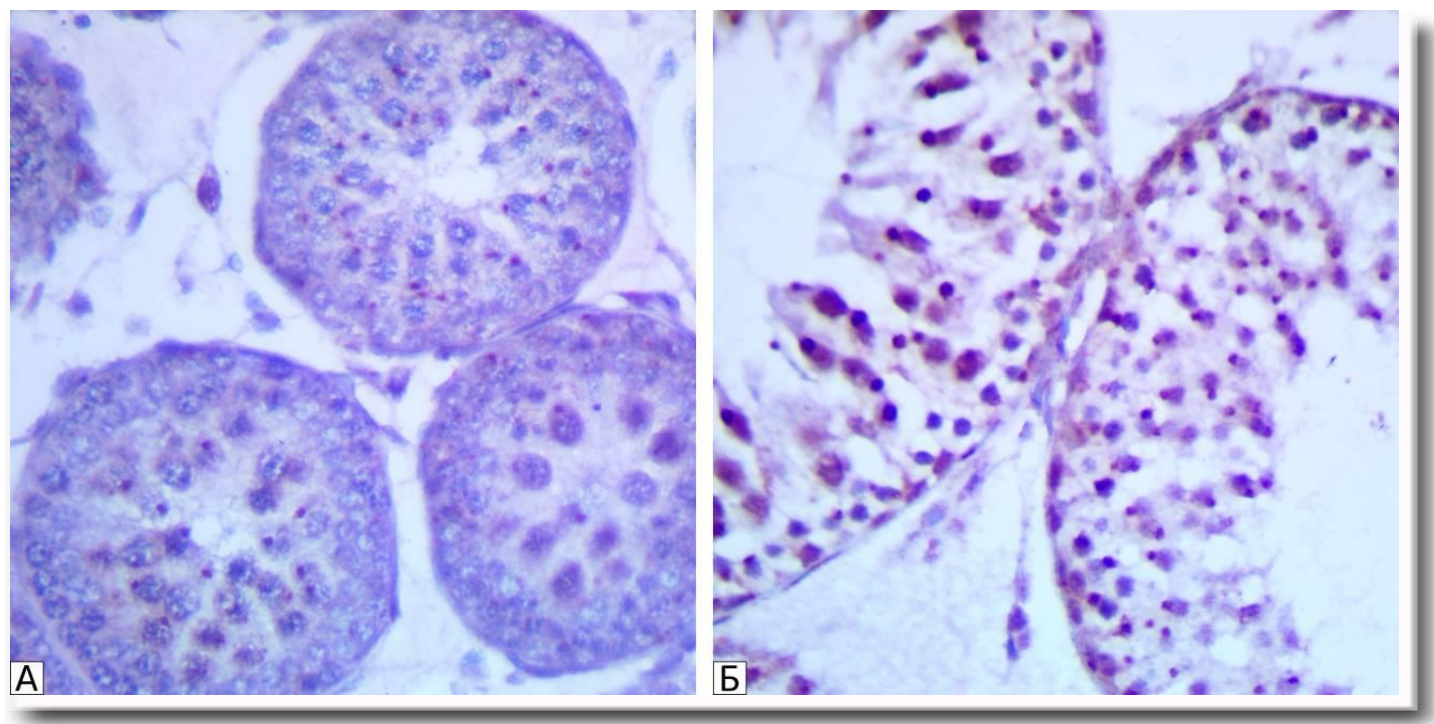

Рис. 3. Гістотопографія фоктора росту судинного ендотелію (VEGF) у яєчках щурів, що розвивалися за умов експериментального гіпотирозу материнського організму, на 20-у (А) та 40-у (Б) добу постнатального онтогенезу. ×560. 


\section{Підсумок}

Проведене дослідження продемонструвало, що морфогенез яєчок потомства, яке розвивалося за умов гіпотирозу материнського організму, супроводжується локальним підвищенням імунореактивності сперматогенних клітин на 20-у та 40-у постнатальну добу з маркером проліферації Кі-67, акросом - 3 фактором росту судинного ендотелію (VEGF). Зміни імунореактивності поєднувалися зі зменшенням розмірів сперматогенних клітин, втратою ними округлої форми, руйнуванням синцитіальних комплексів, що служить віддзеркаленням дегенеративних змін у сім'яних трубочках, правдоподібно, за рахунок активації процесів апоптозу, зростанням кількості макрофагів і клітин Лейдіга в інтерстиційній сполучній тканині.

\section{Перспективи подальших досліджень}

Схарактеризувати активність процесів апоптозу упродовж морфогенезу яєчка потомства за фізіологічних умов та на тлі материнського гіпотирозу і порівняти отримані дані з результатами імуногістохімічного визначення маркерів проліферації.

\section{Інформація про конфлікт інтересів}

Потенційних або явних конфліктів інтересів, що пов'язані з цим рукописом, на момент публікації не існує та не передбачається.

\section{Джерела фінансування}

Дослідження проведено в рамках науководослідної теми «Лектино- та імуногістохімічний аналіз вуглеводних детермінант нормальних та патологічно змінених клітин і тканин» (номер державної реєстрації 0117U001076).

\section{Літературні джерела References}

1. Pankiv VI. [Practical thyroidology]. Donetsk: Zaslavskyi; 2011. 224 p. Ukrainian.

2. Prystupiuk OM. [Hypothyroidism: alterations of organs and systems]. Mezhdunarodnyi Endocrinologicheskiy Zhurnal. 2011;4(36):104-109.

3. Boelaert K, Franklyn JA. Thyroid hormones in health and disease. $J$ Endocrinology. 2005; 187:1-15.

4. Nazarpour S, Tehrani FR, Simbar M, Azizi F. Thyroid disfunction and pregnancy outcomes. Iran J Reprod Med. 2015; 13(7):387-396.

5. Vrijkotte TGM, Hrudey EJ, Twickler MB. Early maternal thyroid function during gestation is associated with fetal growth, particularly in male newborns. J Clinical Endocrinology Metabolism. 2017; 102(3): 1059-1066.

6. Jannini EA, Ulisse S, D’Armiento M. Thyroid hormone and male gonadal function. Endocrine Rev. 1995;16(4):443-459.

7. Singh R, Hamada AJ, Agarwal A. Thyroid hormones in male reproduction and fertility. The Open Reproductive Science Journal. 2011;3:98-104.

8. Wagner MS, Wajner SM, Maia AL. The role of thyroid hormone in testicular development and function. J Endocrinol. 2008;199:351-365. DOI: 10.1677/JOE-08-0218.

9. Wagner MS, Wajner SM, Maia AL. Is there a role for thyroid hormone on spermatogenesis? Microsc Res Tech. 2009;72(11):796-808.

10. Buzzard JJ, Morrison JR, O’Bryan MK, Song Q. Developmental expression of thyroid hormone receptors in the rat testis. Biol Reprod. 2000;62(3):664-669.

11. Gao Y, Lee WM, Cheng CY. Thyroid hormone function in the rat testis. Front Endocrinol. 2014:1-19. DOI.org/10.3389/fendo.2014.00188.
12. Romano RM, Gomes SN, Cardoso NC, Schiessl L. New insight for male infertility revealed by alterations in spermatic function and differential testicular expression of thyroid-related genes. Endocrine. 2017;55(2):607-617.

13. Cooke PS. Thyroid hormone and the regulation of testicular development. Anim Reprod Sci. 1996;42:333-341.

14. Jiang JY, Umezu M, Sato E. Characteristics of infertility and the improvements of fertility by thyroxine treatment in adult male hypothyroid rdw rats. Biol Reprod. 2000;63(6):1637-1641.

15. Holsberger DR, Cooke PS. Understanding the role of thyroid hormone in Sertoli cells development: a mechanistic hypothesis. Cell Tissue Res. 2005;322(1):133-140.

16. Maran RR, Aruldhas MM. Adverse effects of neonatal hypothyroidism on Wistar rats spermatogenesis. Endocr Res. 2002;28(3):141-154.

17. Maran RR, Arunakaran J, Aruldhas MM. T3 directly stimulates basal and modulates LH induced testosterone and oestradiol production by rat Leydig cells in vitro. Endocr J. 2000;47:417-428.

18. Anbalagan J, Sashi AM, Vengatesh J, Stanley JA. Mechanism underlying transient gestationalonset hypothyroidism-induced impairment of posttesticular sperm maturation in adult rats. Fertil Steril. 2010;93:2491-2497.

19. Shegedin AYu, Yashchenko AM, Lutsyk AD. Influence of maternal hypothyroidism on the postnatal development of rat testes as detected by morphometric and lectin histochemistry analysis. Acta Medica Leopoliensia. 2017;23(3):85-93.

20. Parker GA, Picut CA, eds. Atlas of histology of the juvenile rat. Amsterdam: ElsevierAcademic Press, 2016:227-236. 
Шегедін А.Ю., Амбарова Н.О., Ященко А.М. Імуногістохімічне дослідження яєчок потомства щурів, що розвивалося за умов експериментального гіпотирозу материнського організму.

РЕФЕРАТ. Актуальність. Захворювання щитоподібної залози належать до найпоширеніших ендокринних патологій, впливаючи на морфогенез та гістофізіологію численних органів. Мета. Дослідити вплив експериментального гіпотирозу материнського організму на закономірності розвитку яєчок потомства з використанням імуногістохімічного маркера клітинної проліферації Кі-67 та фактора росту судинного ендотелію VEGF. Методи. Гіпотироз викликали щоденним згодовуванням самкам щурів антитироїдного препарату Мерказоліл з розрахунку 10 мг/кг маси протягом двох тижнів до початку вагітності, упродовж усього гестаційного періоду та лактації. Для імуногістохімічного дослідження були використані яєчка потомства на 1-у, 10-у, 20-у та 40-у доби постнатального розвитку після фіксації у суміші Буена і заливки у парафін. Результати. Встановлено, що на 1-у постнатальну добу маркер Ki-67 локалізувався у складі перинуклеарної зернистості гоноцитів, розташованих у центральній частині сім'яних тяжів. За умов гіпотирозу додатково до гоноцитів імунореактивність проявляли макрофаги та клітини Лейдіга, кількість яких була підвищеною у порівннні з контролем. На 10-у постнатальну добу на тлі цілковитої ареактивності гоноцитів і сперматогоній помірно маркувалися клітини Сертолі. У тварин експериментальної групи виявлено дисперсний розподіл рецепторів Кі-67 з їх накопиченням на периферії сім'яних тяжів та у складі клітин Лейдіга. На 20-у постнатальну добу реактивність Кі-67 було ідентифіковано у складі сперматогенних клітин сім'яних трубочок. На тлі гіпотирозу інтенсивність мітки зростала у поєднанні зі збільшенням розмірів та відсутністю просвіту сім'яних трубочок, збільшенням у їхньому складі кількості сперматогенних клітин. На 40-у постнатальну добу маркувалися переважно ядра сперматогоній; гіпотироз індукував підвищення їхньої імунореактивності. Гістотопографія фактора росту судинного ендотелію VEGF загалом була подібною до розподілу маркера Ki-67, що свідчить про пряму кореляційну залежність інтенсивності проліферації клітин від їхнього забезпечення киснем. На відміну від маркера Ki-67, який локалізувався переважно у складі ядра та зони комплексу Гольджі, VEGF-імунореактивність була ідентифікована у складі цитоплазматичної зернистості, зокрема, акросомальних гранул ранніх сперматид на 20-у та 40-у доби постнатального розвитку. Висновки. Морфогенез яєчок потомства, яке розвивалося за умов гіпотирозу материнського організму, супроводжується збільшенням кількості макрофагів і клітин Лейдіга у ранньому постнатальному періоді. Зростання імунореактивності сперматогенних клітин у поєднанні зі збільшенням їх кількості, порушеннями форми і розмірів, руйнуванням синцитіальних комплексів на 20-у та 40-у постнатальні доби свідчить про посилення проліферації у поєднанні із затримкою дозрівання сперматозоїдів та дегенеративними змінами у сім'яних трубочках.

Ключові слова: імуногістохімія, морфогенез яєчок щура, материнський гіпотироз.

Шегедин А.Ю., Амбарова Н.А., Ященко А.М. Иммуногистохимическое исследование семенников потомства крыс, которое розвивалось в условиях экспериментального гипотиреоза материнского организма.

РЕФЕРАТ. Актуальность. Заболевания щитовидной железы принадлежат к наиболее распространенным эндокринопатиям, оказывающим существенное влияние на морфогенез и гистофизиологию многочисленных органов. Цель. С использованием иммуногистохимического маркера клеточной пролиферации Кi-67 и фактора роста сосудистого эндотелия (VEGF) изучить влияние экспериментального гипотиреоза материнского организма на развитие яичек потомства. Методы. Гипотиреоз индуцировали ежедневным скармливанием самкам крыс антитиреоидного препарата Мерказолил из расчета 10 мг/кг массы в течении двух недель до покрытия, на протяжении всей беременности и периода лактации. Для иммуногистохимического исследования были использованы семенники потомства на 1-е, 10-е, 20-е и 40-е сутки постнатального развития после фиксации в смеси Буэна и заливки в парафин. Результаты. Установили, что на 1-е сутки постнатального онтогенеза маркер Ki-67 локализовался в составе перинуклеарной зернистости гоноцитов, расположенных в центральной части семенных тяжей. В условиях гипотиреоза дополнительно к гоноцитам имунореактивнисть проявляли макрофаги и клетки Лейдига, количество которых повышалось по сравнению с контролем. На 10-е постнатальные сутки на фоне полной ареактивности гоноцитов и сперматогоний умеренно маркировались клетки Сертоли. У животных экспериментальной группы выявлено дисперсное распределение рецепторов Кі-67 с их накоплением на периферии семенных тяжей и в цитоплазме клеток Лейдига. На 20-е постнатальные сутки имунореактивнисть была идентифицирована в составе сперматогенных клеток семенных трубочек. На фоне гипотиреоза интенсивность имунной метки возрастала в сочетании с увеличением диаметра семенных трубочек, осутствием в их составе просвета и увеличением количества сперматогенных клеток. На 40-е постнатальные сутки Кі-67 маркировал преимущественно ядра сперматогоний; гипотиреоз индуцировал повышение их иммунореактивности. Гистотопография фактора роста сосудистого эндотелия VEGF в целом напоминала таковую маркера Ki-67, что свидетельствует о прямой коррелятивной зависимости интенсивности пролиферации клеток от их насыщенности кислородом. В отличие от маркера Ki-67, для котрого была характерной ло- 
кализация преимущественно в составе ядра и зоне комплекса Гольджи, VEGF-иммунореактивность была идентифицирована в составе цитоплазматической зернистости, в частности, в акросомальных гранулах ранних сперматид на 20-е и 40-е сутки постнатального развития. Выводы. Морфогенез яичек потомства, которое розвивалось в условиях гипотиреоза материнского организма, сопровождался увеличением количества макрофагов и клеток Лейдига в раннем постнатальном периоде. Повышение иммунореактивности сперматогенных клеток в сочетании с увеличением их количества, нарушениями формы и размеров, разрушением синцитиальных комплексов на 20-е и 40-е сутки постнатального онтогенеза свидетельствует об усилении пролиферации в сочетании с задержкой созревания сперматозоидов и дегенеративных изменениях в семенных трубочках.

Ключевые слова: иммуногистохимия, морфогенез яичек крысы, материнский гипотиреоз. 